\title{
PENERAPAN TEKNOLOGI TEPAT GUNA PEMBUATAN PERMEN FUNGSIONAL DARI DAUN SIRIH PADA KWG ST. IG. LOYOLA BOGOR
}

\author{
Hardoko $^{1,2^{*}}$, Wenny SL. Sinaga ${ }^{1}$, Adolf JN Parhusip ${ }^{1}$, Yuniwaty Halim ${ }^{1}$, Titri S. Mastuti ${ }^{1}$, Jessica Decyree ${ }^{1}$ \\ ${ }^{1}$ Jurusan Teknologi Pangan, Fakultas Sains dan Teknologi, Universitas Pelita Harapan \\ Jl. Thamrin Boulevard 0-0, Lippo Karawaci Tangerang 15811 \\ ${ }^{2}$ Prodi Teknologi Hasil Perikanan, Fakultas Perikanan dan Ilmu Kelautan, Universitas Brawijaya
} Jl. Veteran No. 1 Malang 65113

hardoko.fti@uph.edu dan hardoko@ub.ac.id, wenny.sinaga@uph.edu, adolf.parhusip@uph.edu, yuniwaty.halim@uph.edu, titri.mastuti@uph.edu, jessica.decyree@uph.edu

\begin{abstract}
Abstrak
Kelompok Wanita (KWG) St. Ig. Lolyola Bogor dalam kegiatannya tidak hanya melakukan kegiatan pendalaman iman tetapi juga kegiatan non-agama yang berguna untuk diaplikasikan pada masyarakat sekitarnya. KWG ini membutuhkan berbagai teknologi tepat guna untuk pembinan anggotanya dan juga masyarakat sekitar. Pengabdian Kepada Masyarakat (PKM) ini bertujuan untuk mengajarkan teknologi tepat guna pembuatan permen fungsional dari daun sirih. Metode yang digunakan dalam PKM adalah metode Participatory Active Learning System (PALS). Hasilnya menunjukkan bahwa teknologi pembuatan permen fungsional dari daun sirih bisa dipelajari, dipahami, dan mudah diprektekkan di KW dan juga bisa diaplikasikan dirumah dan dimasyarakat sekitarnya. Permen daun sirih yang dihasilkan dapat berfungsi untuk kesehatan secara umum dan kesehatan mulut secara khusus, sehinggga dapat disebut permen fungsional.
\end{abstract}

Kata Kunci : daun sirih, permen fungsional, KWG, teknologi

\section{PENDAHULUAN}

Permen banyak disukai oleh berbagai kalangan masyarakat mulai dari anak-anak sampai orang dewasa. Pada umumnya orang mengkonsumsi permen jarang dengan maksud untuk memperoleh gizi, melainkan umumnya untuk kesenangan atau untuk mendapatkan sensasi tertentu. Kesukaan orang terhadap permen adalah terkait dengan rasa manis dari gula yang dapat dikombinasikan dengan rasa yang lain. Rasa manis dari permen adalah terkait dengan tingginya kandungan gula pada permen. Dengan demikian permen juga dapat berdampak negatif pada orang yang mengkonsumsi seperti sakit gigi dan beberapa penyakit yang lain seperti hiperglukemia. Oleh karena itu perlu dimodifikasi agar permen tidak memberikan dampak negatif tetapi dapat menjadi media untuk mencegah atau menyembuhkan suatu penyakit. Salah satu caranya adalah dengan menambahkan zat-zat alami yang bersifat fungsional untuk kesehatan. Hal ini seiring dengan kesadaran masyarakat akan pentingnya hidup sehat yang semakin meningkat. Bahan alami yang ditambahakan dapat berupa vitamin, mineral, dan atau senyawa bioaktif yang bermanfaat untuk kesehatan.

Salah satu bahan alami yang mengandung bioaktif adalah daun sirih. Fadlilah (2015) dan Lutviandhitarani et al (2015) menyatakan bahwa daun sirih dapat berperan sebagai antibiotik (green antibiotik). Hal ini ditunjang oleh laporan penelitian bahwa daun sirih bersifat antibakteri dan juga anti jamur (Wahyudi, 2012; Amrulloh, 2008; Gunawan, 2010; Maytasari, 2010). Bahkan daun sirih juga dilaporkan sebagai antioksidan (Hermiati et al,

$$
\text { Teknologi Tepat Guna }
$$


2013), antihiperglikemia (Salim, 2006; Kendran et al, 2013), antiimflamasi (Fitriyani et al., 2011). Hernani et al (1991) menyatakan bahwa daun Sirih (Piper betle) memiliki keunggulan seperti menghentikan pendarahan gusi, menghilangkan bau mulut, mengobati sariawan, mencegah bau badan serta sebagai obat batuk. Sirih juga dapat menguatkan gigi (Koesmiati, 1996). Kandungan senyawa antibakteri dalam sirih dapat bekerja pada bakteri gingivitis (aerob dan anaerob) dan bakteri pembentuk plak (Streptococcus mutans-c dan Streptococcus mutans) (Suwondo et al., 1992). Aplikasi sifat bioaktif daun sirih telah dilakukan pada pasta gigi (Mutmainnah, 2013) dan tablet hisap (Gusmayadi dan Azwar, 2014).

Berdasarkan karkateristik dari daun sirih sebagai bioaktif, maka dapat diaplikasikan pada permen keras yang banyak disukai oleh banyak kalangan masyarakat, sehingga permen keras bisa menjadi media bagi kesehatan masyarakat. Selin itu, teknologi pembuatan permen keras termasuk sederhana dan dapat dilakukan dalam skala industri kecil atau rumahtangga.

Salah satu media untuk menyampaikan infromasi permen fungsional untuk kesehatan adalah Kelompok Wanita (KW) Gereja St. Ignatius Loyola, Semplak, Bogor. Kelompok ini mempunyai kegiatan untuk membina anggotanya dan juga kegiatan membina masyarakat sekitar gereja. Kegiatan yang dilakukan didasarkan pada potensi sumberdaya yang dimiliki dan pengembangannya, baik dalam bentuk penyuluhan dan atau pelatihan. Permasalahannya adalah $\mathrm{KW}$ ini kurang memiliki informasi tentang daun sirih pada hal mereka memiliki tanaman sirih dan belum negetahui teknologi pembuatan permen keras. Oleh karena itu perlu dilakukan Pelatihan Pembuatan Permen Daun Sirih Sebagai Antimikroba sebagai bentuk kepedulian kampus terhadap kesehatan masyarakat. Kegiatan ini sebagai bentuk perwujudan salah satu Tridarma Perguruan Tinggi yaitu Kegiatan Pengabdian Kepada Masyarakat (PKM).

\section{METODE}

Metode yang digunakan pengabdian masyarakat tentang pembuatan permen daun sirih sebagai antimikroba adalah metode sistem pembelajaran dengan partisipasi aktif (Participatory Action Learning Syatem = $P A L S)$. Metode ini diterapkan untuk pemberdayaan kelompok jemaat wanita Gereja (KWG) St. Ignatius Loyola. Prinsip dasar penerapan metode ini adalah pelibatan anggota kelompok jemaat Gereja St. Ignatius Loyola dalam proses pembelajaran aktif partisipan dalam program PKM. Metode PALS menitik beratkan pada transformasi pada kegiatan yang telah ada untuk diusahakan dibawa pada perubahan-perubahan kearah perbaikan pemanfaatan daun sirih sebagai anti mikroba. Metode PALS terbagai dalam kegiatan : 1) Pelatihan dalam bentuk praktek pembuatan permen daun Sirih; 2) Evaluasi terhadap pelaksanaan kegiatan PKM menggunakan Form evaluasi.

\section{Cara Pembuatan Permen Daun Sirih}

Bahan yang digunakan adalah berupa daun sirih, sirup jagung, gula pasir, dan air. Daun sirih dibuat ekstrak dengan cara mencampur daun sirih dengan air hangat (1:3), dihancurkan dengan blender, disaring dengan kain saring sehingga diperoleh ekstrak daun sirih. Sementara itu, dipanaskan sirup jagung dan gula dengan rasio 1:1 (b/v) dan ditambahkan ekstrak daun sirih sebanyak $30 \%$, kemudian dipanaskan sampai $140^{\circ} \mathrm{C}$ dan dituang dalam cetakan permen. Setelah dingin membeku dilepaskan dari cetakan sehingga diperoleh permen daun sirih.

\section{Evaluasi Kegiatan PKM}

Kegiatan PKM dievaluasi secara langsung menggunakan Tabel 1.

Tabel 1. Form evaluasi PKM

\begin{tabular}{ll}
\hline 1. Apakah anda pernah & $\square$ belum \\
mengikuti kegiatan PKM? & $\square$ sudah \\
\hline 2. Jika pernah ikuti kegiatan & $\square$ kurang \\
PKM. Penyelenggara .......... & $\square$ cukup \\
Topik .............. & $\square$ sangat \\
Manfaat dari PKM tsb.. & bermanfaat \\
\hline
\end{tabular}




\begin{tabular}{|c|c|}
\hline $\begin{array}{l}\text { 3. Apakah anda pernah } \\
\text { mengikuti PKM dengan } \\
\text { topik sama dengan saat ini? }\end{array}$ & $\begin{array}{l}\square \text { pernah } \\
\square \text { belum }\end{array}$ \\
\hline $\begin{array}{l}\text { 4. Jika anda pernah, apakah } \\
\text { topik saat ini memberikan } \\
\text { wawasan atau hal baru? }\end{array}$ & $\begin{array}{l}\text { tidak } \\
\square \text { kurang } \\
\square \text { banyak }\end{array}$ \\
\hline $\begin{array}{l}\text { 5. Apakah jenis kegiatan PKM } \\
\text { saat ini sesuai dengan latar } \\
\text { belakang Anda? }\end{array}$ & $\begin{array}{l}\square \text { tidak sesuai } \\
\square \text { kurang sesuai } \\
\square \text { sesuai } \\
\end{array}$ \\
\hline $\begin{array}{l}\text { 6. Apakah jenis PKM saat ini } \\
\text { dapat diikuti dengan baik? }\end{array}$ & $\begin{array}{l}\square \text { tidak dapat } \\
\square \text { kurang dpat } \\
\square \text { dapat diikuti } \\
\end{array}$ \\
\hline $\begin{array}{l}\text { 7. Apakah topik yang diberikan } \\
\text { menarik? }\end{array}$ & $\begin{array}{l}\square \text { tidak } \\
\square \text { cukup } \\
\square \text { sangat menarik }\end{array}$ \\
\hline $\begin{array}{l}\text { 8. Apakah jenis kegiatan PKM } \\
\text { kali ini berguna bagi anda? }\end{array}$ & $\begin{array}{l}\square \text { tidak } \\
\square \text { berguna } \\
\square \text { sangat guna }\end{array}$ \\
\hline $\begin{array}{l}\text { 9. Apakah pelaksanaan PKM } \\
\text { saat ini berjalan dengan baik? }\end{array}$ & $\begin{array}{l}\square \text { kurang baik } \\
\square \text { baik } \\
\square \text { sangat baik }\end{array}$ \\
\hline $\begin{array}{l}\text { 10. Apakah penyuluh dapat } \\
\text { memberikan infromasi } \\
\text { dengan baik? }\end{array}$ & $\begin{array}{l}\square \text { kurang baik } \\
\square \text { baik } \\
\square \text { sangat baik }\end{array}$ \\
\hline $\begin{array}{l}\text { 11. Apakah media yang digu- } \\
\text { nakan mudah dimengerti? }\end{array}$ & $\begin{array}{l}\square \text { tidak mudah } \\
\square \text { kurang mudah } \\
\square \text { mudah }\end{array}$ \\
\hline $\begin{array}{l}\text { 12. Setelah kegiatan PKM ini } \\
\text { selesai, apakah tindak lanjut } \\
\text { anda? } \\
\square \text { ingin coba lagi dan teruskan } \\
\text { ke orang lain }\end{array}$ & $\begin{array}{l}\square \text { ingin coba lagi } \\
\text { dan tdk ingin } \\
\text { teruskan ke } \\
\text { orang lain } \\
\square \text { tidak ingin } \\
\text { coba lagi } \\
\end{array}$ \\
\hline $\begin{array}{l}\text { 13. Kesan, pesan dan saran } \\
\text { kegiatan PKM ini }\end{array}$ & 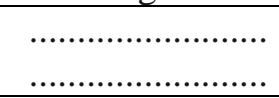 \\
\hline
\end{tabular}

\section{HASIL DAN PEMBAHASAN}

Kegiatan PKM mengikutsertakan 30 orang peserta yang merupakan anggota KWG St. Ig. Loyola. Kegiatan penyuluhan ini diawali dengan pemaparan materi dan dilanjutkan dengan prkatek pembuatan produk permen daun sirih. Peserta dapat melakukan tanya jawab seiring dengan pemaparan materi, kemudian peserta juga ikut terlibat langsung proses pembuatan produk permen sirih. Antusiasme peserta terlihat jelas dengan banyaknya peserta yang mengajukan pertanyaan dan ikut berpartisipasi aktif dalam kegiatan praktek yang dilakukan. Secara keseluruhan, acara berlangsung dengan baik dan mendapatkan respon positif dari para peserta. Foto kegiatan PKM dapat dilihat pada Gambar 1.

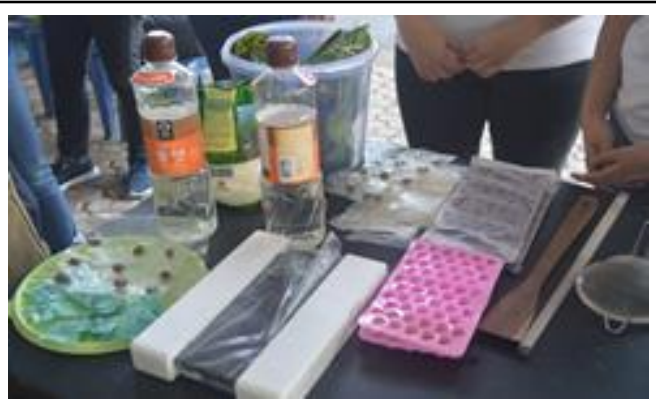

A. Bahan dan Alat Pembuatan Permen

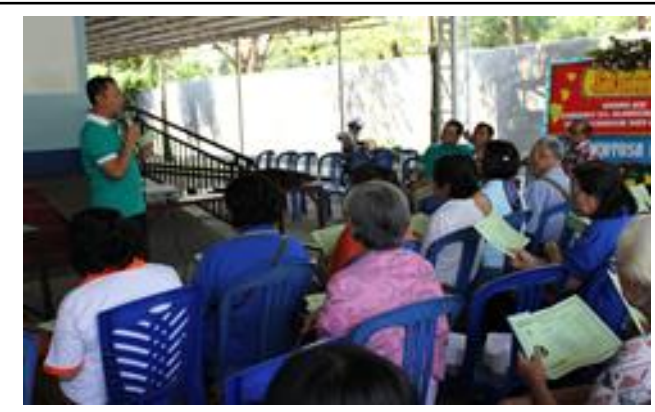

B. Penjelasan pembuatan permen Daun sirih
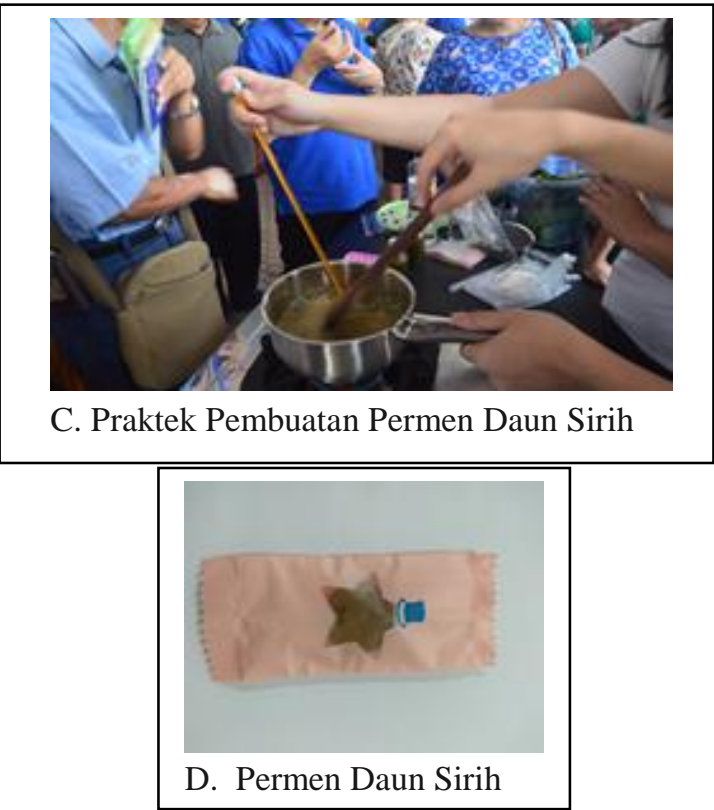

Gambar 1. Foto-foto kegiatan PKM 
Permen yang dibuat dalam penyuluhan dan pelatihan ini adalah termasuk permen yang berfungsi untuk kesehatan, karena menambahkan ekstrak daun sirih. Hal ini terkait dengan fungsi daun sirih untuk berbagai penyakit. Hernani et al (1991) menyatakan bahwa daun Sirih (Piper betle) memiliki keunggulan seperti menghentikan pendarahan gusi, menghilangkan bau mulut, mengobati sariawan, mencegah bau badan serta sebagai obat batuk. Sirih juga dapat menguatkan gigi (Koesmiati, 1996). Kandungan senyawa antibakteri dalam sirih dapat bekerja pada bakteri gingivitis (aerob dan anaerob) dan bakteri pembentuk plak (Streptococcus mutans$c$ dan Streptococcus mutans-d) (Suwondo et al., 1992). Dengan demikian melalui PKM ini dapat mengedukasi masyarakat untuk memanfaatkan sumber daya yang ada disekitar dengan teknologi yang sederhana menjadi produk yang disukai masyarakat dan bisa dijual. Selain itu, PKM ini juga mengedukasi masyarakat untuk memilih permen yang berfungsi untuk kesehatan, khususnya terkait dengan kesehatan mulut.

\section{Hadil Evaluasi Kegiatan PKM}

Hasil Evaluasi kegiatan PKM berdasarkan form evaluasi Tabel 1 disajikan pada Tabel 2.

Tabel 2. Hasil evaluasi pelaksanaan PKM

\begin{tabular}{clc}
\hline $\begin{array}{c}\text { No. } \\
\text { Pertanyaan }\end{array}$ & Jenis jawaban & $\begin{array}{c}\text { Persentase } \\
\text { jawaban } \\
(\%)\end{array}$ \\
\hline 1 & A. Belum pernah & 20 \\
& B. Pernah & 80 \\
\hline 2 & A. Kurang & 0 \\
& B. Cukup & 30 \\
& C. Sangat bermanfaat & 70 \\
\hline 3 & A. Pernah & 0 \\
& B. Tidak pernah & 100 \\
\hline 4 & A. Tidak & - \\
& B. Kurang & - \\
& C. Banyak & - \\
\hline
\end{tabular}

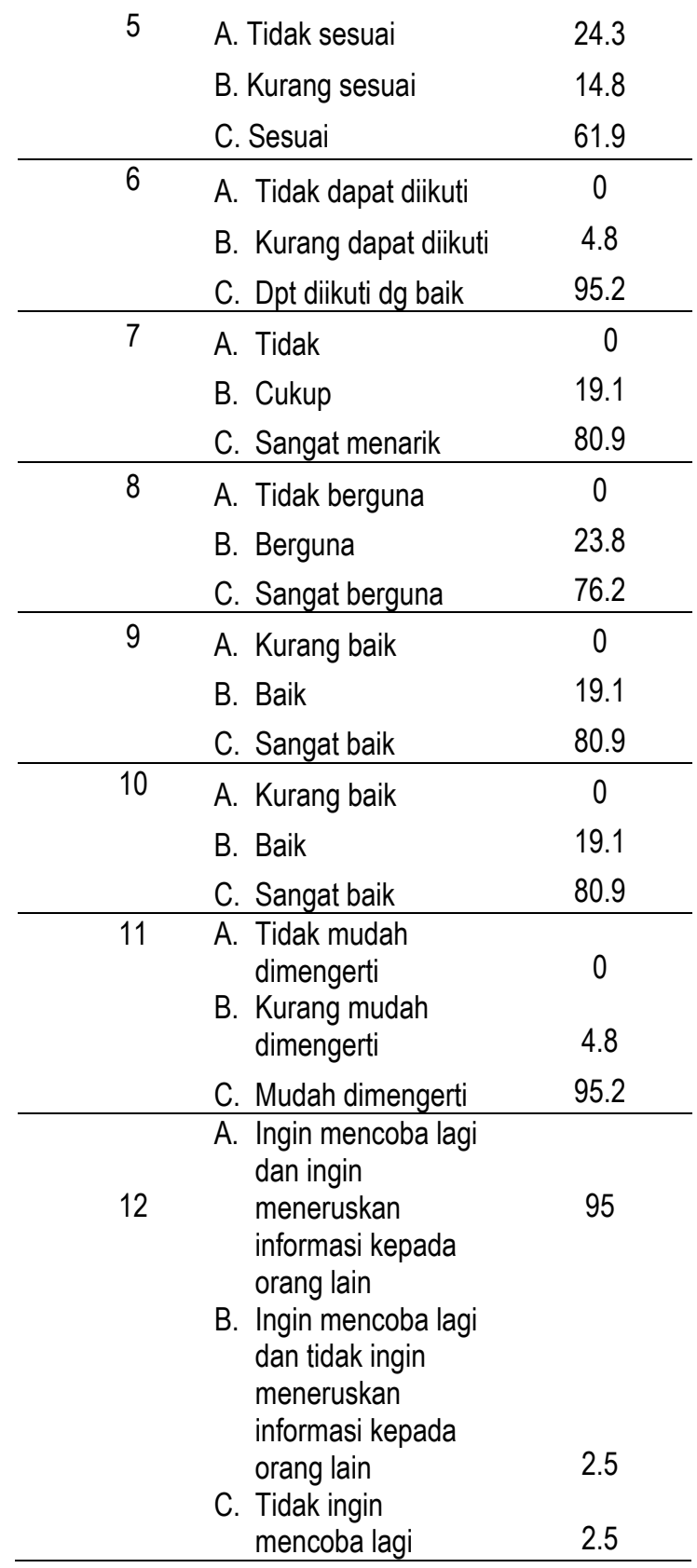

Berdasarkan hasil evaluasi pada Tabel 2, terlihat bahwa peserta PKM memberikan respon positif terhadap pelaksanaan kegiatan PKM di KWG St. Ig. Loyola. Sebanyak $80 \%$ peserta belum pernah mengikuti kegiatan penyuluhan seperti yang dilakukan pada PKM ini. Akan tetapi, 80.9\% peserta merasa topik yang dibawakan sangat menarik dan sebanyak 76.2\% menyatakan jenis kegiatan PKM ini sangat bermanfaat. Peserta juga menyatakan bahwa 
penyuluh dapat memberikan informasi dengan baik dan media yang digunakan juga mudah dimengerti oleh para peserta. Selain itu, 95\% peserta ingin mempraktekkan lagi dirumahnya dan meneruskan informasi teknologi pengolahan permen kepada orang lain. Dengan demikian dapat dikatakan bahwa teknologi pembuatan permen sirih dapat dipahami dan diadopsi oleh pseserta pelatihan.

Hasil kuesioner ini menunjukkan bahwa kegiatan PKM dalam bentuk penyuluhan dan pelatihan sangat berguna bagi para peserta dan dapat dilakukan lagi di kemudian hari, tetapi dengan topik yang lain. Model PKM ini dilakukan untuk mendorong anggota atau kelompoknya melakukan kegitan yang produktif dan menghasilkan uang.

\section{KESIMPULAN}

Pelatihan dan penyuluhan diikuti oleh 30 orang anggota KWG St. Ignatius Loyola dengan antusiasme dan partisipasi aktif yang tinggi dari peserta.

Teknologi pembuatan permen sirih yang bermanfaat untuk kesehatan dapat dipahami dan diadopsi oleh peserta pelatihan yaitu KWG St. Ig. Loyola.

\section{UCAPAN TERIMAKASIH (Bila ada)}

Ucapan terima kasih disampaikan kepada Yayasan Pelita Harapan yang telah mendanai PKM ini melalui LPPM UPH No PM-016/FaST/V/2017.

\section{REFERENSI}

Amrulloh, I. (2008). Uji Potensi Ekstrak Daun Sirih (Piper betle L.) Sebagai Antimikroba Terhadap Bakteri Xanthomonas oryzae dan Jamur Fusaroum oxysporum. Malang : Univeristas Islam Negeri. Skripsi.

Fadlilah, M. (2015). Benefit of Red Betel (Piper crocatum Ruiz \& Pav.) as Antibiotics. Jurnal Majority 4(3):71-75.

Fitriyani A, Winarti L, Muslicah S, \& Nuri, A. (2011). Uji Antiinflamasi Ekstrak Metanol Daun
Sirih Merah (Piper crocatum Ruiz\&Pav) Pada Tikus Putih. Majalah Obat Tradisional 16(1):34-42.

Gunawan, S. (2010). Mekanisme Daya hambat Kombinasi Ekstrak Daun Sirih Hijau (Piper betle L.) dan Daun Sirih Merah (Piper crotatum) Terhadap Pertumbuhan Candida albicans. Surabaya : Fakultas Kedokteran Gigi, Universitas Airlangga. Skripsi.

Gusmayadi I, \& Azwar N. (2014). Pengaruh Kombinasi Aspartam-Sorbitol Sebagai Bahan Pemanis Terhadap Sifat Fisik Tablet Hisap Ekstrak Daun Sirih (Piper betle L.) Secara Granulasi Basah. Jurnal Prospek Farmasi 1(1): 32-39.

Hermiati, Rusli, Manalu, NY, \& Sinaga MS, (2013). Ekstrak Daun Sirih Hijau dan Merah Sebagai Antioksidan Pada Minyak Kelapa. Jurnal Teknik Kimia USU 2(1):37-43.

Hernani, \& Yuliani S. (1991). Peranan Sirih sebagai obat tradisional. Warta Tumbuhan Obat Indonesia 1(1):13-14.

Kendran AAS, Gelgel KTP, Pertiwi NW., Anthara MS, Dharmayuda AGO, \& Anggreni LD. (2013). Toksisitas Ekstrak Daun Sirih Merah pada Tikus Putih Penderita Diabetes Melitus. Jurnal Veteriner 4:527-533.

Koesmiati, S. (1996). Daun sirih (Piper betle Linn) sebagai desinfektan. Bandung : Departemen Farmasi. Institut Teknologi Bandung. Skripsi.

Lutviandhitarani G, Harjanti DW, \& Wahyono F. (2015). Green Antibiotic Daun Sirih (Piper betle L.) Sebagai Pengganti Antibiotik Komersial Untuk Penanganan Mastitis. Agrivet 15(1):28-32

Maytasari, G.M. (2010). Perbedaan Antifungi Minyak Atsiri Daun Sirih Hijau, Minyak Atsiri Daun Sirih Merah, dan Resik-V Sabun Sirih Terhadap Pertumbuhan candida albicans Secara Invitro.) Solo : Fakultas Kedokteran Universitas Sebelas Maret. Skripsi 
Mutmainah, M. (2013). Pengaruh Pasta Gigi Yang Mengandung Ekstrak Daun Sirih Dalam Mengurangi Plak dan Gingivitis Pada Gingivitis marginalis Kronis. Makasar : Fakultas Kedokteran Gigi, Universitas Hasanuddin. Skripsi.

Salim, A. (2006). Potensi Rebusan daun Sirih Merah Sebagai Antihiperglikemia Pada Tikus Putih Galur Spargue-Dawley. Bogor : Program Studi Biokimia Fakultas MIPA, IPB. Skripsi.

Suwondo,S, Sidik, S, Sumadilaga RS, \& Soelarko RM. (1992). Aktivitas Antibakteri Daun Sirih (Piper betle L.) terhadap Bakteri Gingivitis dan
Bakteri Pembentuk Plak / Karies Gigi (Streptococcus mutans). Warta Tumbuhan Obat Indonesia 1(1):1-9

Wahyudi, RD. (2012). Perbedaan Efektivitas Antibakteri Antara Ekstrak Daun Sirih Merah (Piper crotatum) dan Ekstrak Daun Sirih Hijau (Piper betle L.) Terhadap Porphyromonas gingivalis. Jember : Fakultas Kedokteran Gigi, Universitas Jember. Skripsi. 